\title{
Aquatic Phoretic Mites (Acari: Hydrachnidia) Associated with Ectoparasitism of Mosquitoes (Diptera: Culicidae) in the Midwest Region of Brazil
}

\author{
Fábio Alexandre Leal dos Santos ${ }^{1,2}$, Sirlei Frank Thies', Aldimara Vaillant Gonçalves ${ }^{2}$, \\ Klaucia Rodrigues Vasconcelos², Monaly da Silva Ribeiro², Junio de Souza Damasceno, ${ }^{3,4}$ \\ Elisangela Santana de Oliveira Dantas ${ }^{1,2}$, Diniz Pereira Leite Júnior 1,2,5* \\ ${ }^{1}$ Medical Entomology Laboratory, Faculty of Medicine, Federal University of Mato Grosso, UFMT, \\ Cuiabá, Brazil \\ ${ }^{2}$ University Center of Várzea Grande (UNIVAG), Cristo Rei, Várzea Grande, Brazil \\ ${ }^{3}$ Pontifical Catholic University of Minas Gerais, Postgraduate Program in Vertebrate Biology, Conservation \\ Genetics Laboratory, Belo Horizonte, Brazil \\ ${ }^{4}$ University Center of Belo Horizonte, Institute of Engineering and Technology (IET), Belo Horizonte, Brazil \\ ${ }^{5}$ Laboratory of Investigation, Faculty of Medicine, Federal University of Mato Grosso, UFMT, \\ Cuiabá, Brazil \\ Email: alexandre3021@gmail.com, stthies@hotmail.com, euaaldimara@hotmail.com, artessmt@hotmail.com, \\ monaly_ribeiro@hotmail.com, jdamascenobh@gmail.com, sdelisangela@gmail.com, *djbiologico@gmail.com
}

Received 22 May 2016; accepted 11 July 2016; published 14 July 2016

Copyright (C) 2016 by authors and Scientific Research Publishing Inc.

This work is licensed under the Creative Commons Attribution International License (CC BY).

http://creativecommons.org/licenses/by/4.0/

(c) (i) Open Access

\section{Abstract}

Water mites (Hydrachnidia) are common external parasites of the medically important mosquitoes (Culicidae). Between April 2014 and April 2015, 64 mites from three genus, Arrenurus 71.9\%,

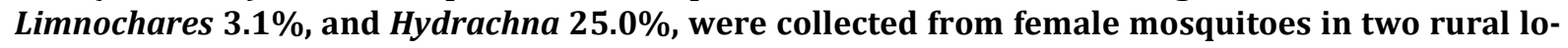
cations near Cuiabá, Mato Grosso, Brazil. Dipterous species parasitized by water mites belonging to seven species: Anopheles (Nys.) darling, An. evansae, Aedes (Och.) scapularis, Ae. serratus, Mansonia (Man.) wilsoni, Psorophora (Jan.) ferox, Ps. varipes. The most common specimens to accommodate the water mites were Anopheles (Nys.) darlingi and Psorophora (Jan.) varipes. The prevalence of parasitism of mosquitoes by water mites found in this study was less than 5 . However, few studies have addressed the ecological role of mites and their biotopes, as well as host-parasite interactions in Brazil.

\footnotetext{
*Corresponding author.

How to cite this paper: dos Santos, F.A.L., Thies, S.F., Gonçalves, A.V., Vasconcelos, K.R., da Silva Ribeiro, M., de Souza Damasceno, J., de Oliveira Dantas, E.S. and Júnior, D.P.L. (2016) Aquatic Phoretic Mites (Acari: Hydrachnidia) Associated with Ectoparasitism of Mosquitoes (Diptera: Culicidae) in the Midwest Region of Brazil. Advances in Entomology, 4, $141-150$. http://dx.doi.org/10.4236/ae.2016.43015
} 


\section{Keywords}

\section{Ectoparasitism, Hydracarina, Culicidae, Mites}

\section{Introduction}

Like most animals, insects belonging to Dipteran may be parasitized. In particular, water mites are known to parasitize the larvae and pupae of these insects by piercing the exoskeleton and ingesting the circulating hemolymph [1] [2]. These mosquitoes can transmit numerous pathogens to their hosts, such as protozoa, viruses, bacteria, nematodes, cestodes, and trematodes [3] [4].

Water mites are found in various environments that are accessible to animals, with many specimens found in soil, plant shoots, animal hair, feathers, human hair follicles, and insect hosts [5]. The habitats for water mites are very diverse. For instance, they are able to live in hot springs, wetlands, temporary pools, ponds, deep lakes, torrential waterfalls, and oceans [1]. According to Smith and Cook [1], water mites are the most abundant and diverse arthropods that exist in moist environments, and they have a life cycle that includes three larval and nymphal stages (ninfocrisalida, deutonymph, and imagocrisalida).

Water mites (Hydrachnida) are an interesting group of microarthropods, with about 6000 described species among 50 families [1] [6]. These organisms are commonly found in vegetation margins of lakes and rivers [1] and occasionally they use to live in water.

Mites are known to parasitize vertebrates as well as insects and other arthropods [7] in study conducted in Egypt indicate that larvae of several species of water mites are ectoparasites of adult mosquitoes and midges, the majority of which belong to the genera Thyas (Thyasidae) and Arrenurus (Arrenuridae). Nielsen [8] in the Denmark also found in their studies, water mites parasitizing adult mosquitoes of the genera Aedes and Anopheles; the majority of mites identified as the genus Thyas and Arrenurus.

The subfamily Arrenurinae Wolcott, 1905 (Arrenuridae Thor, 1900), particularly the genus Arrenurus, has the greatest abundance of species among water mites, with more than 950 known species [9].

Larvae of the Arrenuridae family are ectoparasites of mosquitoes of medical importance, for example, genera Aedes and Anopheles [10]. According to Uchida \& Miyazaki [11], larvae Arrenurus spp. are the most common water mites parasites of mosquitoes, being associated as hosts of various Dipteran genera of medical and veterinary importance (Culex, Anopheles, Mansonia and Coquillettidia).

These water mites are recognized as potential natural enemies of mosquitoes such as Anopheles spp. (the vectors of malaria). Anopheles and Mansonia are the most frequent hosts in the tropics and subtropics; at times $80 \%$ of their populations may be parasitized [12]-[15] suggested in their studies, and these mites can be used as markers of dispersion studies of mosquitoes and as indicators of the age of this dipteran.

In this study, we aimed to identify mite isolated from female Culicidae specimens, as well as to document the preference and occurrence on Culicidae specimens captured in two areas located in the rural municipality Cuiabá, state of Mato Grosso, central region of Brazil, has a tropical climate, conducive to mosquito breeding and represented by three biomes: Amazon, Cerrado, and Pantanal. This might be the first record of genera of water mites hosted in isolated and identified mosquitoes in region Midwestern of Brazil.

\section{Materials and Methods}

The first collection site was located under a bridge where motorway MT-040 crosses the Aricazinho river at $15^{\circ} 56^{\prime} 09.93 " \mathrm{~S}$ and $55^{\circ} 58^{\prime} 25.48^{\prime \prime} \mathrm{W}$; the second was located next to motorway MT-050 near the district of Praia Grande at $15^{\circ} 45^{\prime} 49.82^{\prime \prime S}$ and $56^{\circ} 08^{\prime} 53.91 " \mathrm{~W}$.

The mite-isolated stocks occurred related to collections of mosquitoes in the research project Medical Entomology Laboratory of the Federal University of Mato Grosso and identifying mosquitoes noted the existence of some winged specimens parasitized by mite bodies.

Mosquitoes were captured, between April 2014 and April 2015 from two forest areas in the rural area of Cuiabá, Mato Grosso, Brazil. They were conducted 12 insert the field in four areas assessed, during the seasons of the year, where culicids were captured quarterly. Mite specimens were identified in mosquitoes collected in these two areas with proximity to rivers and streams. The collections of winged specimens were conducted in 
the evening at twilight, comprising the period from 17:00 to 20:00, with three hours of capture on three consecutive days.

Using the suction tube designed by Forattini [16] and Marcondes [17] and transported to the Laboratory of Entomology, Department of Health, state of Mato Grosso mosquitoes were killed by placing in a $-20^{\circ} \mathrm{C}$ freezer for $5 \mathrm{~min}$. Then, they were each examined on a slide and using a stereo microscope at $40 \times$ magnification were identified to the species level with the taxonomic keys of Consoli \& Lourenço-de-Oliveira [18] and Forattini [16].

The anatomical sites where each parasite was located were observed closely. Mites were photographed, their attachment sites recorded, and then removed from their host for identification with the aid of a stereoscopic microscope, and decryption keys and identification of species [9] [19]-[28] for reference.

\section{Results}

Mosquitoes (1362) were collected and classified into 17 species. Of the total number of mosquitoes captured and examined, 30 specimens were infested, with a prevalence of 2.2\%. Four different genera: Anopheles, Aedes, Mansonia and Psorophora were found parasitized, these seven species of insects: Anopheles (Nys.) darlingi (9; 30\%); Anopheles (Nys.) evansae (1; 3.3\%), Aedes (Och.) scapularis (6; 20\%), Aedes (Och.) serratus (2; 6.7\%); Mansonia (Man.) wilsoni (1; 3.3\%); Psorophora (Jan.) ferox (5; 16.7\%), and Psorophora (Jan.) varipes (6; 20\%) (Table 1).

These ectoparasites were from the families Arrenuridae, Limnocharidae, and Hydrachnidae, comprising three genera: Arrenurus spp. (46; 71.9 \%) (Arrenuridae: Arrenurinae) were found in species of Anopheles (Nys.) darlingi, Anopheles (Nys.) evansae, Aedes (Och.) scapularis, Psorophora (Jan.) varipes, and Psorophora (Jan.) ferox. Two specimens (2.3\%) of Limnochares spp. (Limnocharidae: Limnocharinae) were isolated: one derived from Anopheles (Nys.) darlingi (Figure 1) and the other from Aedes (Och.) scapularis; and specimens (16; 25\%) of Hydrachna spp. (Hydrachnidae: Hydrachninae) were isolated from Aedes (Och.) serratus, Psorophora (Jan.) varipes, and Mansonia (Man.) wilsoni. The 15 male mosquitoes captured in this study were not parasitized. All females captured and identified showed higher parasitism rates: Anopheles (Nys.) darlingi (25; 39.1\%), followed by Psorophora (Jan.) varipes (13; 20.3\%).

When we considered the influence of temporal and spatial distribution in two sites, we obtained an index of species richness of parasitic mites of 1.11, which is considered as low richness. Mites are in greater quantity in the genera of Anopheles mosquitoes and Psorophora. When the abundance of parasitic mites on mosquitoes was

Table 1. Water mite parasitism of mosquitoes captured Aricazinho and Praia Grande river in Cuiabá, Mato Grosso, Brazil, 2014-2015.

\begin{tabular}{|c|c|c|c|c|c|c|c|}
\hline \multirow{2}{*}{ Mosquito Species } & \multicolumn{2}{|c|}{$\begin{array}{l}\text { Mosquitoes } \\
\text { captured }\end{array}$} & \multicolumn{2}{|c|}{$\begin{array}{l}\text { Parasitized } \\
\text { mosquitões }\end{array}$} & \multicolumn{2}{|c|}{ Mites } & \multirow{2}{*}{ Mites genus } \\
\hline & $\mathbf{N}$ & $\%$ & $\mathbf{N}$ & $\%$ & $\mathbf{N}$ & $\%$ & \\
\hline $\begin{array}{l}\text { Anopheles (Nys.) darlingi } \\
\text { (Root, 1926) }\end{array}$ & 414 & 34.4 & 9 & 30.0 & 25 & 39.1 & Arrenurus spp./Limnochares spp. \\
\hline $\begin{array}{l}\text { Anopheles (Nys.) evansae } \\
\text { (Brethes, 1926) }\end{array}$ & 23 & 1.9 & 1 & 3.3 & 2 & 3.1 & Arrenurus spp. \\
\hline $\begin{array}{l}\text { Aedes (Och.) scapularis } \\
\quad \text { (Rondani, 1848)* }\end{array}$ & 212 & 17.6 & 6 & 20.0 & 8 & 12.5 & Arrenurus spp./Limnochares spp. \\
\hline $\begin{array}{l}\text { Aedes (Och.) serratus } \\
\text { (Theobald, 1901) }\end{array}$ & 18 & 1.5 & 2 & 6.7 & 5 & 7.8 & Hydrachna spp. \\
\hline $\begin{array}{c}\text { Mansonia (Man.) wilsoni } \\
\text { (Barreto \& Coutinho, 1944) }^{*}\end{array}$ & 48 & 4.0 & 1 & 3.3 & 1 & 1.6 & Hydrachna sp. \\
\hline $\begin{array}{l}\text { Psorophora (Jan.) ferox } \\
\text { (Von Humboldt, 1819) }^{*}\end{array}$ & 78 & 6.5 & 5 & 16.7 & 10 & 15.6 & Arrenurus spp. \\
\hline $\begin{array}{l}\text { Psorophora (Jan.) varipes } \\
\text { (Coquillett, 1904) }\end{array}$ & 410 & 34.1 & 6 & 20.0 & 13 & 20.3 & Arrenurus spp./Hydrachna spp. \\
\hline Total & 1203 & 100 & 30 & 100 & 64 & 100 & \\
\hline
\end{tabular}

*Gaffigan et al. (2015) Systematic Catalog of Culicidae. WRBU-New Mosquito Classification [59]. 
compared; Anopheles (Nys.) darlingi hosted the largest number, 25 mites (39.1\%) belonging to species Arrenurus spp. For the insect genus Psorophora, we found 10 (15.6 \%) individuals in Arrenurus spp., Psorophora (Jan.) ferox (Figure 2).

The distribution patterns of mites collected in the regions of Praia Grande and Aricazinho River were different for mosquito species: Anopheles (Nys.) darling, Aedes (Och.) serratus and Psorophora (Jan.) varipes were found to host Arrenurus spp. and Hydrachna spp. On the other hand, mosquitoes collected on the Aricazinho river, Anopheles (Nys.) darling, Anopheles (Nys.) evansae, Aedes (Och.) scapularis, Mansonia (Man.) wilsoni, Psorophora (Jan.) varipes and Psorophora (Jan.) ferox, were found parasitized by Arrenurus spp., Limnochares spp., and Hydrachna spp.

These aquatic mites were distributed on the basis of the anatomical region of the mosquitoes as follows: in the head along with the neck: three on Anopheles (Nys.) darling, five on Aedes (Och.) serratus, one on Mansonia (Man.) wilsoni, and six on Psorophora (Jan.) varipes; in the region of the abdomen: in regions I and II tergites, seven mites on Anopheles (Nys.) darlingi; II and III, two mites on Aedes evansae; III and IV, three mites on Aedes scapularis; and IV and V, one on Aedes (Och.) scapularis. In the abdominal tergites (I to V) of an Anopheles (Nys.) darlingi were isolated from 10 Arrenurus spp. mites parasitizing (Figure 3). In the pronotum, we found four mites on Anopheles (Nys.) darlingi and Psorophora (Jan.) varipes (Table 2).

Table 2. Distribution anatomical region of mosquitoes; parasitized by water mite captured Aricazinho and Praia Grande river in Cuiabá, Mato Grosso, Brazil, 2014-2015.

\begin{tabular}{|c|c|c|c|c|c|c|c|c|c|c|c|c|c|c|c|c|}
\hline & \multicolumn{4}{|c|}{ Subfamily Anophelinae } & \multicolumn{10}{|c|}{ Subfamily Culicinae } & \multicolumn{2}{|c|}{ Geral } \\
\hline & A.d. & $\%$ & A.e. & $\%$ & A.s.a. & $\%$ & A.s. & $\%$ & M.w. & $\%$ & P.v.a. & $\%$ & P.f. & $\%$ & Total & $\%$ \\
\hline \multicolumn{17}{|c|}{ I. Anatomical region } \\
\hline Head/neck & 3 & 12 & - & - & 5 & 100 & - & - & 1 & 100 & 6 & 46 & - & - & 15 & 23 \\
\hline Chest & 4 & 16 & - & - & - & - & 4 & 50 & - & - & 7 & 54 & 8 & 80 & 23 & 36 \\
\hline Abdome & 17 & 68 & 2 & 100 & - & - & 4 & 50 & - & - & - & - & 2 & 20 & 25 & 39 \\
\hline Legs & 1 & 4 & - & - & - & - & - & - & - & - & - & - & - & - & 1 & 2 \\
\hline Total & 25 & 100 & 2 & 100 & 5 & 100 & 8 & 100 & 1 & 100 & 13 & 100 & 10 & 100 & 64 & 100 \\
\hline
\end{tabular}

II. Abdome distribution

\begin{tabular}{|c|c|c|c|c|c|c|c|c|c|c|c|c|c|c|c|c|}
\hline I ao V & 10 & 58.8 & - & - & - & - & - & - & - & - & - & - & - & - & 10 & 40 \\
\hline I e II & 7 & 41.2 & - & - & - & - & - & - & - & - & - & - & - & - & 7 & 28 \\
\hline II e III & - & - & 2 & 100 & - & - & - & - & - & - & - & - & 2 & 100 & 4 & 16 \\
\hline III e IV & - & - & - & - & - & - & 3 & 75 & - & - & - & - & - & - & 3 & 12 \\
\hline IV e V & - & - & - & - & - & - & 1 & 25 & - & - & - & - & - & - & 1 & 4 \\
\hline Total & 17 & 100 & 2 & 100 & - & - & 4 & 100 & - & - & - & - & 2 & 100 & 25 & 100 \\
\hline
\end{tabular}

III. Chest distribution

$\begin{array}{ccccccccccccccccc}\text { Mesopleura } & 2 & 50 & - & - & - & - & 2 & 50 & - & - & 2 & 29 & 4 & 50 & 10 & 43 \\ \text { Sternumpleura } & - & - & - & - & - & - & 2 & - & - & - & 2 & 29 & 2 & 25 & 6 & 26 \\ \text { Pronotum } & 2 & 50 & - & - & - & - & - & - & - & - & 2 & 29 & - & - & 4 & 18 \\ \text { Escutellum } & - & - & - & - & - & - & - & - & - & - & 1 & 13 & 2 & 25 & 3 & 13 \\ \quad \text { Total } & 4 & 100 & - & - & - & - & 4 & 50 & - & - & 7 & 100 & 8 & 100 & 23 & 100\end{array}$

IV. Legs distribution

Posterior tibial

1100

100

Legend: A.d. $=$ Anopheles $($ Nys. $)$ darlingi; A.e. $=$ Anopheles $($ Nys. $)$ evansae; A.s.a. = Aedes $($ Och. $)$ serratus; A.s. $=$ Aedes $($ Och. $)$ scapularis; M.w. $=$ Mansonia (Man.) wilsoni; P.v.a. = Psorophora (Jan.) varipes and P.f. = Psorophora (Jan.) ferox. 


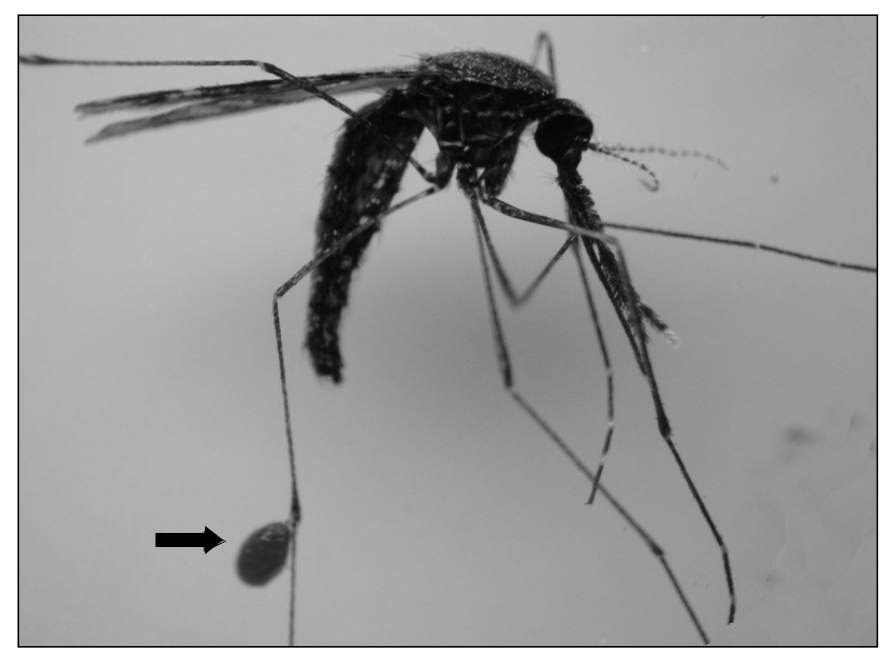

Figure 1. Aquatic mites Limnochares on the posterior tibial Anopheles (Nys.) darlingi female (40× magnification) (picture by Diniz P. Leite-Jr.). The arrow indicates the insertion site.

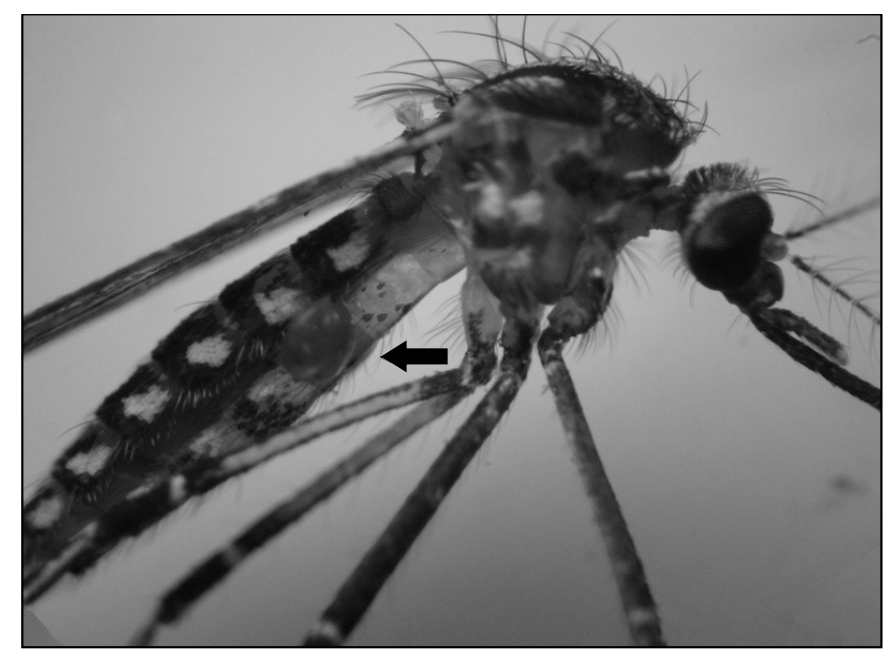

Figure 2. Aquatic mites Arrenurus on the abdomen of Psorophora (Jan.) ferox female (40× magnification) (picture by Diniz P. Leite-Jr.). The arrow indicates the insertion site.

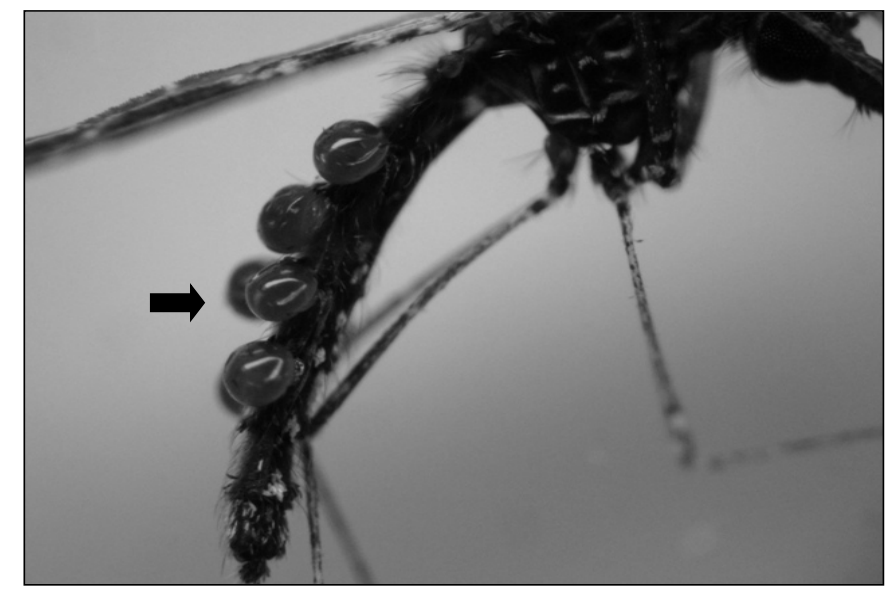

Figure 3. Aquatic mites Arrenurus on the abdomen of Anopheles (Nys.) darling female (40× magnification) (picture by Diniz P. Leite-Jr.). The arrow indicates the insertion site. 


\section{Discussion}

The larvae of aquatic mites are the most common types of ectoparasites Culicidae with medical importance such as Aedes spp. and Anopheles spp. In our study, the overall prevalence of infestation of mites on mosquitoes was 2.2\%. This percentage is relatively high, as compared to other previous findings. In the United States, Milne [29] found a prevalence of $0.27 \%$. In Australia, McCallister [30] reported 0.005\%, Williams and Proctor [31] found 0.27\%. In New Zealand, Snell and Heath [32] found 0.52\%. Kirkhoff [33] reported 2.6\% in Pennsylvania and Spurrier [34], in Wyoming, found in mosquitoes a prevalence of $0.42 \%$ and $0.76 \%$ prevalence over a period of six years. In India, Sharma \& Prasad [34] found a higher prevalence (4.1\%).

Most species of water mites (Acari: Hydrachnidae) are common parasites of emergent aquatic insects and have larvae that are obligate parasites on adult insects order: Odonata, Hemiptera, and Diptera, primarily in the Nematocera, especially Chironomidae, but also including the Culicidae [28] [35].

There are several records of mite parasitism of insects in different circumstances like Peymotidae [36], Odonatas [37] [38], Coleoptera [39], Sand flies [40] [41], Hemiptera [42] [43], and Muscidae [7] [44] [45].

The interaction between mites and mosquitoes has been investigated by several authors in Canada [46], India [35], United States [29] [30], Australia [31], New Zealand [32], and Pennsylvania [33]. In Brazil, there is a report of parasitized mosquitoes in São Paulo city [47]. In Mato Grosso, the country’s central region, no reports on activity of mites on mosquitoes have been documented.

A behavior observed in many families of mites is phoresy phenomenon, which consists of passive transport of an organism for the purpose of dispersion [44]. The dispersion is an important process for many species of mites that allows the expansion of their populations, the colonization of different areas and the escape of natural enemies. In general, structural, physiological and behavioral adjustments associated with the scattering mechanism are common and are varied in mites [44] [48]-[50].

Most water mites that are found to parasitize mosquito larvae belong to the genus Arrenurus [10] [51]. This is confirmed by the findings of this study, in which we removed Arrenurus spp. from mosquitoes [51]. According to Mullen [23], water mites most commonly parasitizing mosquitoes are species of Arrenurus (Arrenuridae) and Thyas (=Parathyas) (Thyasidae).

Members of Arrenuridae, Hydryphantidae, and Erythracidae were described by Williams and Proctor [31], when they analyzed infected mosquitoes of the genera Anopheles, Culex, Ochlerotatus, and Tripteroides in Australia. The first three of these genera were also found in mosquitoes parasitized by larval Arrenuridae and Microtrombidiidae in New Zealand [32]. In 2013, Kirkhoff [33] identified the genera Aedes, Anopheles, Coquillettidia, Culex, Ochlerotatus, Orthopodomyia, and Psorophora parasitized by mites of the genus Parathyas sp. and Arrenurus sp.; 33 different associations and parasitism of individual mosquitoes by more than one species of mites were observed. Our study corroborates this, as we collected and identified mosquitoes of the genus Anopheles, Aedes, Mansonia, and Psorophora parasitized by aquatic micro invertebrates.

Mullen [23] gathered 238 worldwide records of acarine parasites of mosquitoes that were always attached to membranous areas of the host body. In 2010, researchers in Egypt, recorded mite parasites attached in other groups activities: Muscidae, Ceratopogonidae and other dipterans [7]. Mites isolated in this study were located in the ventral and dorsal abdomen and at various positions on both sides of the chest, neck, and legs of mosquitoes.

Mites of the genus Arrenurus (71.9\%) were most commonly found in membranous areas between the thorax and abdominal segments I, II, II, IV and V. We observed a strong tendency for mites to set up on the abdomen of winged hosts. This distribution is probably explained to the ease of attachment to the membranes in the ventral segments and adherence to the abdominal region, which allows easy attachment for mites and access to hemolymph (Table 2).

According Nielsen [8] describes in his study, that mites were always found attached to membranous areas of the host body. In all mosquito species, the most common attachment site was the back of coxae.

With regard to the fixing of ectoparasites to anatomical sites, we observed parasites on the abdomen, chest, head/neck, and legs. Milne [29] and Snell \& Heath [32] reported a similar pattern of attachment of the abdomen mites (Table 2).

The distribution of mites on their hosts may be specific for each species [36]. Indeed, most examples have characteristic locations of connection, which depend on the species, but may also vary with the host species and genera [12] [24] [43] [46]. 
The parasitic mite families Arrenuridae, Hydrachnidae and Limnocharidae which belong to the genera Arrenurus, Hydrachna and Limnochares, are not uncommon, with a number of records involving water mites of these families, parasitizing insects [1] [29] [32] [33].

Water mites are a group of mites living in water and playing a important of predators role in aquatic biocenoses. The distribution and the dispersion degree of different species of water mites are varied depending on the parasitized insects. The water mites parasitizing insects whose imagines constantly stay outside the water are decidedly the more expansive and in general more frequent species in the current fauna [52].

According to Gledhill [53] that predation occurs depending on the migration ability of parasitized insects water and can be divide in three groups: 1) Parasites of insects whose imagines are permanently connected with water; 2) the parasites of insects whose imagines periodically leave water; 3) the parasites of insects whose imagines permanently live out of water.

According to Zawal [52] [54] the third group is composed of the remaining species of water mites, which parasitize flying insects of the orders Odonata, Ephemoroptera, Plecoptera, Heteroptera, Trichoptera and Diptera. These insects are both fairly large and easily accessible for parasites. Dipterans are less intensively infested (several parasites on one host).

Several authors have reported in their casuistic in the most frequently infested insects are family Odonata and dipterans of the families Culicidae [33] [52] [55]-[58].

Water mite larvae parasitize many aquatic insect species, including aquatic Ephemoroptera, Plecoptera, Heteroptera, Trichoptera and Diptera. Although this situation may cause damaging impacts to the hosts, the mites can disperse and colonize new localities in this way. In the Brazil, little is known about the frequency of water mite ectoparasitism amongst the aquatic dipterans in Middle West in the Country. In this study, larval water mite parasitism on aquatic dipterans, families Culicidae and Anophelinae that have been collected from different localities in Cuiabá city, was evaluated. These are the first records for larval mite parasitism on Middle West region in the Brazil.

The high diversity of the taxon, described by some authors, exemplifies its importance. However, there are few studies on the ecological role of mites on their biotopes and their parasite-host interactions. This paper aims to describe the association of these aquatic ectoparasites, first described in Cuiabá, Mato Grosso, Brazil.

Mites can thrive amongst various biological control mosquito populations. We suggest that further studies are needed to map the studied species of mites for the Brazil and in State of Mato Grosso, as well as to identify interactions and associations with other parasitized animal species, aiming to use them as biological markers in the control of insects of medical importance. Further study is necessary to know the extent of competition/ nature and mechanism of toxic substance used by the ectoparasites.

\section{Acknowledgements}

For thank financial support provided by Coordenação de Aperfeiçoamento de Pessoal de Nível Superior (CAPES) and Conselho Nacional de Pesquisa (CNPq)-Brazil.

\section{Conflict of Interest}

The authors declare that there are no conflicts of interest.

\section{References}

[1] Smith, I.M. and Cook, D.R. (1991) Water Mites. In: Covich, T., Ed., Freshwater Invertebrates from North American, Academic Press, Toronto, 523-592.

[2] Gerson, U., Smiley, R.L. and Ochoa, R. (2003) Mites (Acari) for Pest Control. Blackwell Publishing Ltd., Oxford, UK, 12. http://dx.doi.org/10.1002/9780470750995

[3] Wall, R. (2007) Ectoparasites: Future Challenges in a Changing World. Veterinary Parasitology, 148, 62-74. http://dx.doi.org/10.1016/j.vetpar.2007.05.011

[4] Marcondes, C.B. (2009) Transmitted Diseases and Caused by Arthropods. Atheneu, São Paulo, 557.

[5] Flechtmann, C.H.W. (1975) Elements Acarology. Livraria Nobel S.A., São Paulo, 344 p.

[6] Di Sabatino, A., Gerecke, R. and Martin, P. (2000) The Biology and Ecology of Lotic Water Mites (Hydrachnidia). Freshwater Biology, 44, 47-62. http://dx.doi.org/10.1046/j.1365-2427.2000.00591.x 
[7] Mumcuoglu, K.Y. and Braverman, Y. (2010) Parasitic and Phoretic Mites of Diptera in Israel and the Sinai Peninsula, Egypt. Israel Journal of Entomology, 40, 195-203.

[8] Nielsen, B.O. (1998) The Water Mite Thyas barbigera Viets (Hydrachnellae: Thyasidae) Parasitizing Mosquitoes. European Mosquito Control Association, 2, 10-12.

[9] Smit, H. (2012) New Records of the Water Mite Family Arrenuridae from the Afrotropical Region, with the Description of 11 New Species and Two New Subspecies (Acari: Hydrachnidia). Zootaxa, 3187, 1-31.

[10] Stechmann, D.H. (1980) Zum Wirtskreis syntopischer Arrenurus-Arten (Hydrachnellae, Acari) mit parasitischer Entwicklung an Nematocera (Diptera). Zeitschrift für Parasitenkunde, 62, 267-283. http://dx.doi.org/10.1007/BF00926567

[11] Uchida, T. and Miyazaki, I. (1935) Life-History of a Water-Mite Parasitic on Anopheles. Proceedings of the Imperial Academy, 11, 73-76.

[12] Smith, B. (1983) The Potential of Mites as Biological Control Agents of Mosquitoes. In: Hoy, M., Cunningham, G. and Knust, L., Eds., Research Needs for Development of Biological Control of Pest by Mites, Agriculture Experiment Station, University California, 79-85.

[13] Mitchell, R. (1962) Storm-Induced Dispersal in the Damselfly Ischnura verticallis. American Midland Naturalist, 68, 199-202. http://dx.doi.org/10.2307/2422646

[14] Corbet, P.S. (1963) The Reliability of Parasitic Water-Mites (Hydracarina) as Indicators Physiological Age in Mosquitoes (Diptera: Culicidae). Entomologia Experimentalis et Applicata, 6, 215-233. http://dx.doi.org/10.1111/j.1570-7458.1963.tb00620.x

[15] Corbet, P.S. (1970) The Use of Parasitic Water-Mites for Age-Grading Female Mosquitoes. Mosquito News, 30, 436-438.

[16] Forattini, O.P. (2002) Medical Culicidology. EDUSP, São Paulo, 864.

[17] Marcondes, C.B., Alencar, J., Balbino, V.Q. and Guimarães, A.E. (2007) Description of Three Practical and Inexpensive Devices for the Collection of Mosquitoes and Other Small Insects. Journal of the American Mosquito Control Association, 23, 84-86. http://dx.doi.org/10.2987/8756-971X(2007)23[84:DOTPAI]2.0.CO;2

[18] Consoli, R.A.G.B. and Lourenço-de-Oliveira, R. (1994) Main Mosquitoes Health Importance in Brazil. 2nd Edition, FIOCRUZ, Rio de Janeiro, 228.

[19] Prasad, V. and Cook, D.R. (1972) The Taxonomy of Water Mite Larvae. In: Institute AE, Ed., Memoirs of the American Entomological Institute, University of Minnesota, Minneapolis, 326.

[20] Cook, D.R. (1974) Water Mite Genera and Subgenera. The American Entomological Institute.

[21] Cook, D.R. (1980) Studies on Neotropical Water Mites. Memoirs of the American Entomological Institute, 31, 1-645.

[22] Mullen, G.R. (1974) Acarine Parasites of Mosquitoes. II. Illustrated Larval Key to the Families and Genera of Mites Reported by Parasitic on Mosquitoes. Mosquito News, 34, 183-195.

[23] Mullen, G.R. (1975) Acarine Parasites of Mosquitoes I. A Critical Review of All Know Records of Mosquitoes Parasitized by Mites (Acarina: Hydrachnellae). Journal of Medical Entomology, 12, 27-36. http://dx.doi.org/10.1093/jmedent/12.1.27

[24] Smith, I.M. and Oliver, D.R. (1986) Review of Parasitic Associations of Larval Water Mites (Acari: Parasitengona: Hydrachnida) with Insect Hosts. The Canadian Entomologist, 118, 407-472. http://dx.doi.org/10.4039/Ent118407-5

[25] Clifford, H.F. (1990) Aquatic Invertebrates of Alberta. Department of Biological Sciences, University of Alberta, Edmonton. http://sunsite.ualberta.ca/Projects/Aquatic_Invertebrates/?Page=23

[26] Harvey, M.S. (1998) The Australian Water Mites: A Guide to Families and Genera. Vol. 4, CSIRO Publishing, 150.

[27] Walter, D.E. and Proctor, H.C. (1999) Mites: Ecology, Evolution, and Behaviour. Springer, Dordrecht, Netherlands, 494.

[28] Smith, I.M., Cook, D.R. and Smith, B.P. (2009) Water Mites (Hydrachnidia) and Other Arachnids. In: Thorp, J.H. and Covich, A.P., Eds., Chapter 15: Ecology and Classification of North American Freshwater Invertebrates, 3rd Edition, Academic Press, San Diego, 485-586.

[29] Milne, M.A., Townsend, V.J., Smelser, P., Felgenhauer, B.E., Moore, M.K. and Smyth, F.J. (2009) Larval Aquatic and Terrestrial Mites Infesting a Temperate Assemblage of Mosquitoes. Experimental and Applied Acarology, 47, $19-33$. http://dx.doi.org/10.1007/s10493-008-9194-2

[30] McCallister, G.L., Mullins, G.R. and McCallister, Z.G. (1999) Acarine Parasites of Mosquitoes in West Central Colorado. Proceedings of the Annual Meeting of the Utah Mosquito Abatement Association, Park City, UT, 3-5 October 1999.

[31] Williams, C.R. and Proctor, H.C. (2002) Parasitism of Mosquitoes (Diptera: Culicidae) by Larval Mites (Acari: Parasi- 
tengona) in Adelaide, South Australia. Australian Journal of Entomology, 41, 161-163. http://dx.doi.org/10.1046/j.1440-6055.2002.00274.x

[32] Snell, A.E. and Heath, A.C.G. (2006) Parasitism of Mosquitoes (Diptera: Culicidae) by Larvae of Arrenuridae and Microtrombidiidae (Acari: Parasitengona) in the Wellington Region, New Zealand. New Zealand Journal of Zoology, 33, 9-15. http://dx.doi.org/10.1080/03014223.2006.9518426

[33] Kirkhoff, C.J., Simmons, T.W. and Hutchinson, M. (2013) Adult Mosquitoes Parasitized by Larval Water Mites in Pennsylvania. Journal of Parasitology, 99, 31-39. http://dx.doi.org/10.1645/GE-3105.1

[34] Spurrier, M.F. (1998) Mite Parasitism of Mosquitoes in Central Wyoming. Great Basin Naturalist, 58, 184-187.

[35] Sharma, S.N. and Prasad, R.N. (1992) Water Mite (Arrenurus sp.) Parasitizing Mosquitoes in District Shahjahanpur, U.P. Indian Journal of Malariology, 29, 255-258.

[36] Karunaratne, S.H.P.P. and Amerasinghe, F.P. (1992) Water Mite Parasitism in Four Species of Culex Mosquitoes at Kandy, Sri Lanka. Ceylon Journal of Science (Biological Sciences), 22, 40-49.

[37] Da Cunha, U.S., Silva, E.S., de Moraes, G.J. and Vendramim, J.D. (2006) Occurrence of the Mite Pyemotes sp. (Acari: Pyemotidae) in Insect Rearing in Laboratory. Neotropical Entomology, 35, 563-565.

[38] Lajeunesse, M.J., Forbes, M.P. and Smith, B. (2004) Species and Sex Biases in Ectoparasitism of Dragonflies by Mites. Oikos, 106, 501-508. http://dx.doi.org/10.1111/j.0030-1299.2004.13076.x

[39] Lajeunesse, M.J. (2007) Ectoparasitism of Damselflies by Water Mites in Central Florida. Florida Entomologist, 90, 643-649. http://dx.doi.org/10.1653/0015-4040(2007)90[643:EODBWM]2.0.CO;2

[40] Moser, J.C., Konrad, H., Kirisits, T. and Carta, L.K. (2005) Phoretic Mites and Nematode Associates of Scolytus multistriatus and Scolytus pygmaeus (Coleoptera: Scolytidae) in Austria. Agricultural and Forest Entomology, 7, 169-177. http://dx.doi.org/10.1111/j.1461-9555.2005.00261.x

[41] Martinez-Ortega, E., Conesa-Gallego, C.E., Macfarlane, D. and Ward, R.D. (1983) Ectoparasitic Mites on Phlebotomine Sandflies (Diptera: Psychodidae) from Spain. Annals of Tropical Medicine and Parasitology, 77, 545-546.

[42] Shehata, M. and Baker, A. (1996) Mites Infesting Phlebotomine Sandflies in Southern Sinai, Egypt. Medical and Veterinary Entomology, 10, 193-196. http://dx.doi.org/10.1111/j.1365-2915.1996.tb00730.x

[43] Smith, B.P. (1989) Impact of Parasitism by Larval Limnochares aquatica (Acari: Hydrachnidia; Limnocharidae) on Juvenile Gerris comatus, Gerris alacris, and Gerris buenoi (Insecta: Hemiptera; Gerridae). Canadian Journal of Zoology, 67, 2238-2243. http://dx.doi.org/10.1139/z89-316

[44] Zawal, A., Çamur-Elipek, B., Fent, M., Kirgiz, T. and Dzierzgowska, K. (2013) First Observations in Turkish Thrace on Water Mite Larvae Parasitism of Ranatra linearis by Hydrachna gallica (Acari: Hydrachnidia). Acta Parasitologica, 58, 57-63. http://dx.doi.org/10.2478/s11686-013-0106-1

[45] Elzinga, R.J. and Broce, A.B. (1988) Hypopi (Acari: Histiostomatidae) on House Flies (Diptera: Muscidae): A Case of Detrimental Phoresy. Journal of the Kansas Entomological Society, 61, 208-213.

[46] Smith, B.P. and McIver, S.B. (1984) The Patterns of Mosquito Emergence (Diptera: Culicidae; Aedes spp.): Their Influence on Host Selection by Parasitic Mites (Acari: Arrenuridae; Arrenurus spp.). Canadian Journal of Zoology, 62, 1106-1113. http://dx.doi.org/10.1139/z84-161

[47] Flechtmann, C.H.W. (1974) A Case of Mosquito Heavily Parasitized by Water Mite Larvae. Anais da Escola Superior de Agricultura Luiz de Queiroz, 31, 361-366. http://dx.doi.org/10.1590/S0071-12761974000100028

[48] Knee, W., Fober, M.R. and Beaulieu, F. (2013) Diversity and Host Use of Mites (Acari: Mesostigmata, Oribatida) Phoretic on Bark Beetles (Coleoptera: Scolytinae): Global Generalists. Annals of the Entomological Society of America, 106, 339-350. http://dx.doi.org/10.1603/AN12092

[49] Evans, G.O. (1992) Principles of Acarology. CAB International, Wallingford, 563 p.

[50] Binns, E.S. (1982) Phoresy as Migration-Some Functional Aspects of Phoresy in Mites. Biological Reviews, 57, 571620. http://dx.doi.org/10.1111/j.1469-185X.1982.tb00374.X

[51] Munchberg, P. (1954) Zur Kenntnis der an culiciden (Diptera) schmarotzenden Arrenurus-Larven (Hydracarina), sowie ueber die Bedeutung dieser Parasitenfuer Wirt und Mensch. Zeitschrift für Parasitenkunde, 16, 298-312. http://dx.doi.org/10.1007/BF00260194

[52] Zawal, A. (2003) The Role of Insects in the Dispersion of Water Mites. Acta Biologica Universitatis Daugavpiliensis, 3, 9-14.

[53] Gledhill, T. (1985) Report of the Director. Water Mites-Predators and Parasites. Reprinted Freshwater Biological Association Annual Report, 53, 45-59.

[54] Zawal, A. (2008) Morphological Characteristics of Water Mite Larvae of the Genus Arrenurus Dugés, 1834, with Notes on the Phylogeny of the Genus and an Identification Key. Zootaxa, 1765, 1-75. 
[55] Biesiadka, E. and Cichocka, M. (1994) Water Mites (Hydracarina)—Parasites of Water Bungs of the Group Nepomorpha. Polskie Pismo Entomologiczne, 63, 357-368.

[56] Davids, C. (1973) The Water Mite Hydrachna Conjecta Koenike, 1985 (Acari, Hydrachnellae), Bionomics and Relation to Species of Corixidae (Hemiptera). Netherlands Journal of Zoology, 23, 363-429. http://dx.doi.org/10.1163/002829673X00012

[57] Baker, R., Brett, A. and Morley, S. (1991) Water Mite Larvae Parasitic on Insects-A Study of Laval Structures and Host Relationship. In: Dusbábek, F. and Bukva, V., Eds., Modern Acarology, Vol. 1, Academia, Prague and SPD Academic Publishing bv, the Hague, 494-496.

[58] Gledhill, T., Cowlwy, J. and Gunn, J.C. (1982) Some Aspects of the Host: Parasite Relationships between Adult Blackflies (Diptera: Simuliidae) and Larvae of the Water-Mite Sperchon setiger (Acari: Hydrachnellae) in a Small Chalk Stream in Southern England. Freshwater Biology, 12, 345-357. http://dx.doi.org/10.1111/j.1365-2427.1982.tb00628.x

[59] Gaffigan, T.V., Wilderson, R.C., Pecor, J.E., Stoffer, J.A. and Anderson, T. (2015) Systematic Catalog of Culicidae. Walter Reed Biosystematics Unit. http://www.mosquitocatalog.org/

\section{Submit or recommend next manuscript to SCIRP and we will provide best service for you:}

Accepting pre-submission inquiries through Email, Facebook, Linkedin, Twitter, etc A wide selection of journals (inclusive of 9 subjects, more than 200 journals)

Providing a 24-hour high-quality service

User-friendly online submission system

Fair and swift peer-review system

Efficient typesetting and proofreading procedure

Display of the result of downloads and visits, as well as the number of cited articles

Maximum dissemination of your research work

Submit your manuscript at: http://papersubmission.scirp.org/ 